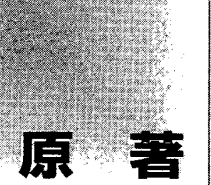

2003年 6 月 1 月 7 日受

2003年12确文理

Code No. 524

\section{治燎計画装置使用時に扣ける最適X線CT画像の検討 一画像ノイズ，スライス厚についてー}

橘 昌幸・木下絵美・平田敬子

\section{緒 言}

放射線治療に扔いて治療計画装置 (radiation treatment planning system，以下，RTPと略す)による線量 分布作成, 線量モ二夕単位 (dose monitor unit, 以下, DMUと略す)の計算の多くは，X-ray computed tomography (以下，CTと略す) 画像による体輪郭の描出，密 度補正等により行われる1, 2). CT值が正確に測定され るのは，最低限の条件であるが，それ以外として，元 データであるCT画像の質によって計算結果に影響が 生じる可能性がある。CT画像の質としては, コント ラスト分解能, 鮮鋭度, ノイズ，スライス厚などが挙 げられる3,4)。これらのなかで，画像ノイズはCTスキ ヤン時の管電流の設定値によって大きく影響される.
九州大学病院放射線部

\begin{abstract}
管電流を高く設定しノイズの少ない画像を得ることも 可能である．また，画像スライス厚は，スライス厚を 薄くスキャンすることにより体軸方向に分解能の高い データを得ることが可能である。しかし，管電流を高 く設定することや薄いスライス厚によるスキャンは, 検查時間, CT装置X線管負荷や被曝線量などが増加す る.そこで，撮影条件およびスライス厚を変化させた 場合のDMUへの影響について検討した.

\section{1. 方 法}

\section{1-1 画像ノイズ}

画像ノイズのDMUへの影響を, CT值による依存性 を確認するため, 数種類の異なるCT值のファントム
\end{abstract}

\title{
Study of Improvement in X-ray Computed Tomography Images with a Radiation Treatment Planning System: Image Noise and Slice Thickness
}

\author{
MASAYUKI TACHIBANA, EMI KINOSHITA, KEIKO HIRATA
}

Department of Radiological Technology, Kyushu University Hospital

Received June 17, 2003; Revision accepted Dec. 25, 2003; Code No. 524

\section{Swmmary}

In radiotherapy, dose distribution and calculation of dose monitor units (DMU) are generally performed by a radiation treatment planning system using CT images. Therefore, differences in calculation can arise as a result of the quality of the CT image data. The quality of CT images involves contrast resolution, resolution, noise, slice thickness, and other factors. Among these factors, we examined noise and slice thicknesses. Results demonstrated that, even if noise increased, CT value did not change, and, therefore, did not influence DMU. Examination of slice thickness showed that, when the radiation field was rectangular, it was not influenced by slice thickness. However, when a multi-leaf collimator (MLC) was used, if slice thickness was thicker than the size of the MLC, a difference arose in the position of the MLC, and, therefore, some difference arose in dose. Therefore, slice thickness should be thinner than the size of the MLC.

Key words: Radiation treatment planning system, Dose monitor unit, Computed tomography image, Slice thickness, Noise 
を作成し，管電流時間積(以下，mAsと略す)を変化さ せスキャンを行い, 数種類のCT值および画像ノイズ の異なる画像を作成し，DMUへの影響を確認した。

CT装置はMX8000(Philips社製)を使用し, 直径 $20 \mathrm{~cm}$ の水円柱ファントムおよび水円柱ファントムに アミドトリゾ酸ナトリウムメグルミン液(日本シエー リング株式会社：ガストログラフィン®)を混ぜCT值 を0, 30, 70, 100, 200, 330，430，500，600HU程 度としたファントムを作成し，スキャンした。スキャ ン条件は, スキャンスライス厚 : $1 \mathrm{~mm} \times 4$ 列, テーブ ル移動速度 : $3.0 \mathrm{~mm} /$ 回転, X線管回転時間 : $0.75 \mathrm{sec} /$ 回転 とし, 画像スライス厚: $3 \mathrm{~mm}, 3 \mathrm{~mm}$ 間隔, 画像再構 成領域 (field of view，以下，FOVと略す）：300mm $\Phi$ の画像を再構成した. 管電圧は $120 \mathrm{kV}$ 一定とし, mAs を20，30，50，100，150，200，245mAs/sliceと変化 させ， 9 種類の画像ノイズの異なる画像を作成した. CT值および画像ノイズの測定は, 水円柱ファントム 中心部抢よび上下左右 $70 \mathrm{~mm}$ 外側の 5 点に $3 \mathrm{~cm} \Phi$ の関 心領域 (region of interest, 以下, ROI と略す)を設定し ROI内の平均 CT值および標準偏差 (standard deviation, 以下, SDと略す)を測定し, SDを画像ノイ ズとした。

作成した画像をRTP Pinnacle ${ }^{3}$ Version 6.0s (ADAC 社製)に転送し，Clinac 21EX 4MV X線（Varian社製） を10Gy投与した場合のDMUを計算し比較を行った。 DMU計算の際には, 線量評価点を水円柱ファントム 中心とした。計算グリッドサイズはRTPの初期設定值 である $4 \mathrm{~mm}$, 計算領域: $20 \times 20 \mathrm{~cm}^{2}$ を一定とし, 照射 野： $10 \times 10 \mathrm{~cm}^{2}$, 線源腫瘍間距離 (source tumor distance, 以下, STDと略す) : $100 \mathrm{~cm}$ とし, 計算アル ゴリズムはcollapsed cone (以下, CCと略す) convolutionを使用した。

\section{1-2 画像スライス厚}

空気中および水ファントム中で $4 \mathrm{~cm}$ の球体ファントム (CT值：490HU) をスキャンし, 数種類の画像スライス 厚の異なる画像を作成し, DMUへの影響を確認した.

$4 \mathrm{~cm}$ の球体ファントムを発泡スチロール上および直 径 $20 \mathrm{~cm}$ の水ファントム中にアクリル系高分子水吸収 剤(ダイナボット株式会社：リセプタル®固形化剂)を 使用し, 水をゲル状にし(以下, 水ゲルと略す), 球体 ファントムを中心に固定しスキャンした．スキャン条 件は，管電圧：120kV，管電流時間積：250mAs/slice, スキャンスライス厚： $1 \mathrm{~mm} \times 4$ 列, テーブル移動速 度：3.0mm/回転, X線管回転時間：0.75 sec/回転とし た。得られた生データより, 画像スライス厚 $1.3,2$, 3，4，5，6，8，10mmの画像を作成した。

画像スライス厚は, $0.5 \mathrm{~mm} \Phi の$ 微小球体ファントム

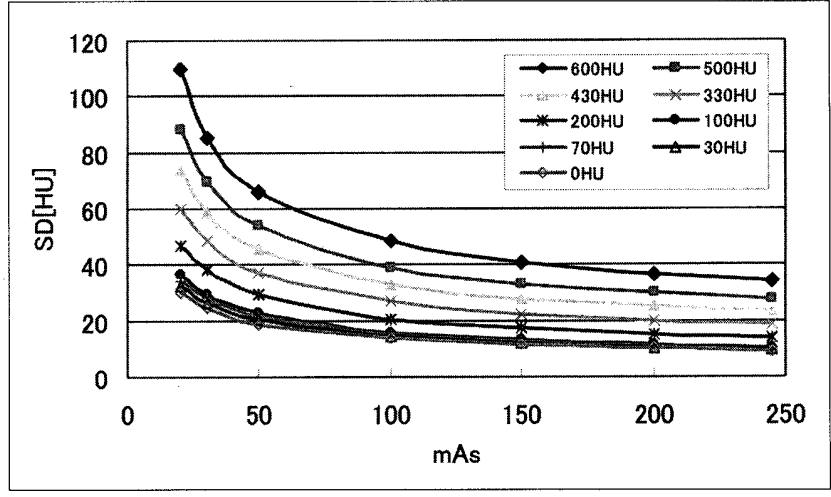

Fig. 1 Change of standard deviation(SD) value for each $\mathrm{CT}$ value at the time of change in mAs.

を使用し，スライス感度プロフィールの測定および半 值幅の測定から確認を行った厚さである ${ }^{5 \sim 7)}$.

作成した画像をRTPに転送し，4MV X線を10Gy投 与した場合のDMUを計算し比較を行った。線量評価 点は球体ファントム中心とした。DMU計算の際に は, 計算グリッドサイズ : $4 \mathrm{~mm}$, 計算領域： $20 \times 20 \mathrm{~cm}^{2}$ を一定とし, 照射野： $5 \times 5 \mathrm{~cm}^{2}$, STD： $100 \mathrm{~cm}$ と, 計算アルゴリズムはCC convolutionを使 用した。

さらに, 球体ファントムからCT值245HUにて境界 設定を行い，さらに $3 \mathrm{~mm}$ のマージンを取り，5mmマ ルチリーフコリメータMillenium 120(Varian社製) (以 下，MLCと略す)を外接で設定した場合におけるMLC のみで構成される照射野面積および $4 \mathrm{MV} \mathrm{X}$ 線を10Gy 投与した場合のDMUを計算した。線量評価点は球体 ファントム中心とした。 MLC使用時の照射野面積 は, MLCの幅 $(5 \mathrm{~mm})$ と各MLCの開度より求めた面積 とした.

\section{2. 結 照}

\section{2-1 画像ノイズ}

Fig. 1に各CT值のファントムにおけるmAs とSDの関 係を示す. CT值 OHUでは20mAsでSD：30，245mAs でSD：8となり, mAsが大きいほどSDは小さくなっ た。この傾向は，CT值600HUでは20mAsでSD： 110，245mAsでSD：32となり, CT值が高いほどその 傾向は大きくなった.

Fig. 2に各CT值ファントムにおけるmAsとCT值との 関係を示す. mAsに影響されずCT值は一定であっ た. Fig. 3にmAsとDMU/Gyとの関係を示す．多少ば らつきはあるが, 各CT值とも mAsに関係なくDMU/Gy はほほ一定であった。

\section{2-2 画像スライス厚}

Fig. 4a，bに正方形照射野における空気中および水 


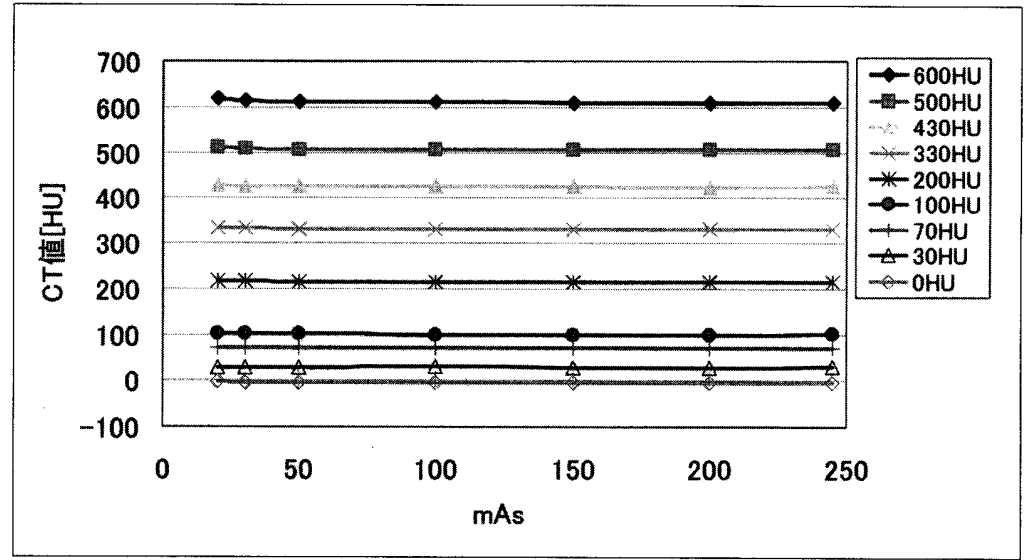

Fig. 2 Change of CT value for each CT value at the time of change in mAs.

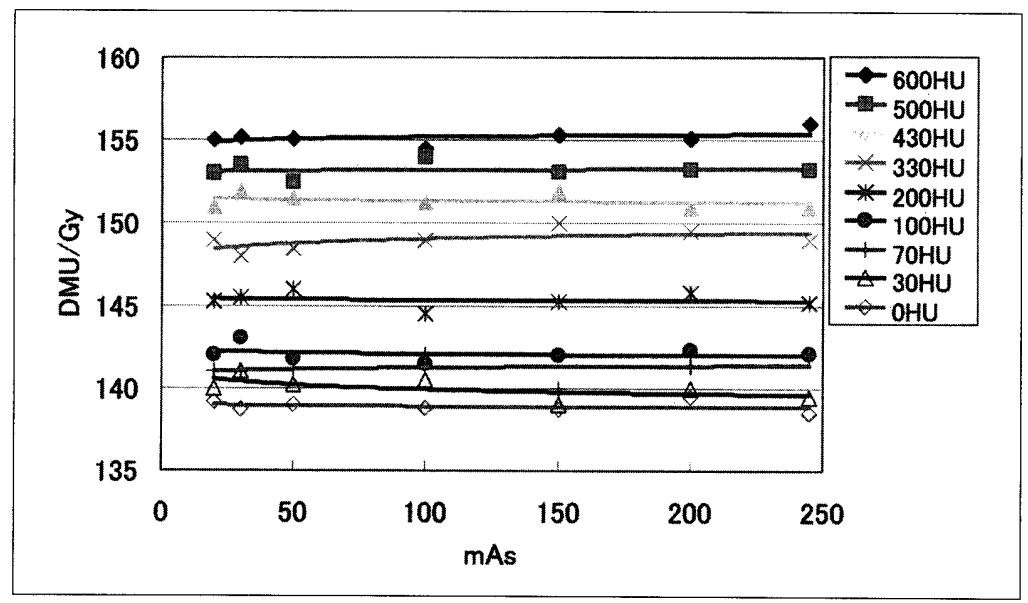

Fig. 3 Change of DMU/Gy for each CT value at the time of change in mAs.
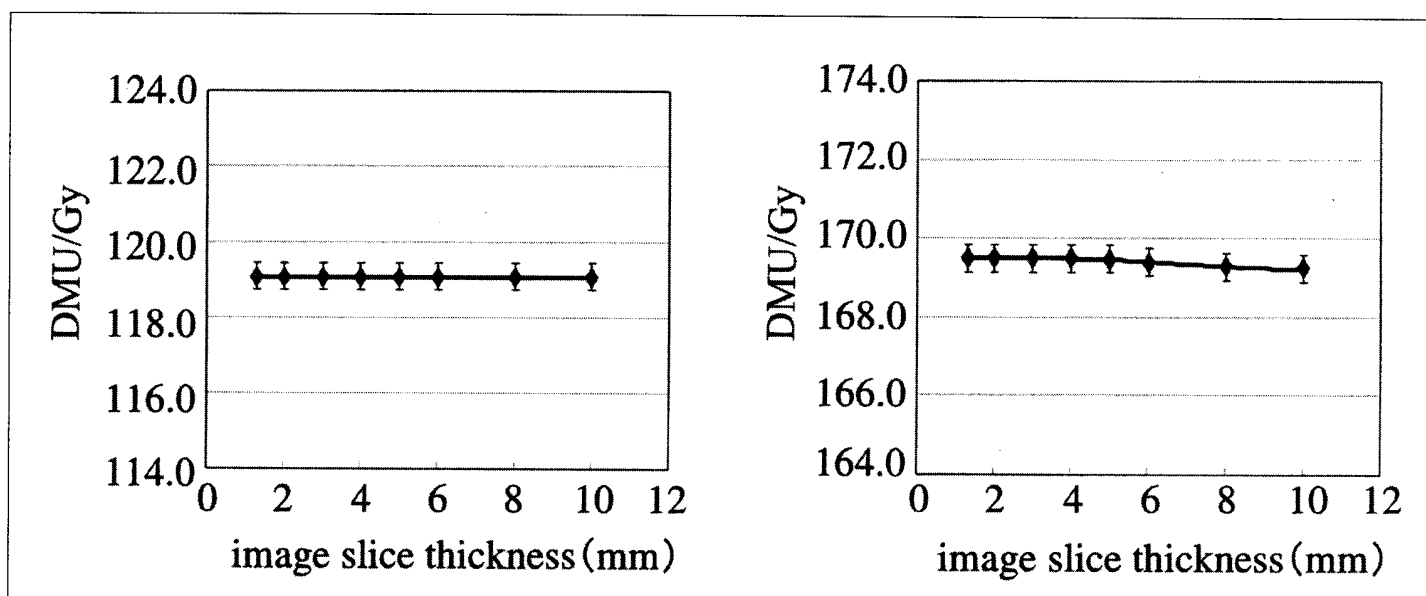

Fig. 4 Change of DMU/Gy at the time of change in image slice thickness.

(a) In air.
(b) In water.

$a \mid b$ 
ゲル中での各画像スライス厚とDMU/Gyの関係を示 す。画像スライス厚に関係なくDMU/Gyは一定であっ た. Fig. 5 に, 球体ファントムに $3 \mathrm{~mm}$ のマージンを取 りMLCを使用した場合の照射野面積を示す. 画像ス ライス厚 $6 \mathrm{~mm}$ まで照射野面積は $18.7 \mathrm{~cm}^{2}$ 前後であった が, 画像スライス厚 $8,10 \mathrm{~mm}$ では, $19.2,19.7 \mathrm{~cm}^{2}$ と なり照射野面積が広がった. Fig. 6に画像スライス厚 1.3，10mmでのMLC位置, Fig. 7に各MLC開度を示 す. 球体ファントム中心部分ではほぼ開度が同じであ るが, 球体ファントムの端のMLCである26, 35番で は画像スライス厚 $1.3 て ゙ 0.6 \mathrm{~cm}$ 開度であるのに対し, 画像スライス厚 $10 \mathrm{~mm} ゙$ は $1.7 \mathrm{~cm}$ となり, MLC開度の 開きが大きくなった. Fig. 8a，bに空気中および水ゲ ル中でのMLCを使用した場合のDMU/Gyを示す. 空 気中では画像スライス厚に関係なくDMU/Gyは一定で

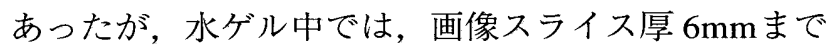
171.7DMU/Gy前後でほほ一定であったが, 画像スラ イス厚 $8,10 \mathrm{~mm}$ で, 170.6, 170.2DMU/Gyと少なく なった。

\section{3. 考 察}

画像ノイズに影響されずDMU/Gyは一定であった。 また，CT值に対する依存性もなかった。これは，画像 ノイズが大きくなった場合, CT画像512×512マトリッ クス内での, 1 画素ごとのCT值のばらつきは大きくな るが，あるROIを設定した場合，そのなかで，ばらつ きが平均化されROI内のSDは变化するが, CT值の平 均值は変化しないからである. 今回の検討においてCT 画像の画素サイズは $0.59 \mathrm{~mm}$ であるが, RTP 上の計算 グリッドサイズは $4 \mathrm{~mm}$ で計算を行ったように, RTPで DMUの計算を行う場合, 計算グリッドはCT画像の画 素サイズょりも大きなサイズで計算されるので, さら にノイズも平均化されてしまうためである。また， 1 枚のスライス面内で画像ノイズが均一でない場合も,

CT值が変化しない限り同じ結果となる。

画像スライス厚は, 正方形照射野の場合, DMU/Gy に差は生じなかった。これは，1枚ごとの画像を考え た場合, 画像スライス厚が厚いと部分体積効果の影響 は大きくなるが，正方形照射野サイズ内で考えた場 合, 画像スライスが積分されたCT值となるため, 画 像スライス厚が厚くても薄くても正方形照射野が一定 でありサイズ内での，積分されたCT值は同じになる ことが考えられる.

MLCを使用した場合，MLCサイズ以上の画像スラ イス厚 8,10mmではMLCの開度に差が生じるため, 照射野面積が大きくなる，このため, DMU/Gyに差が 生じた。 また, 空気中, 水ゲル中でDMU/Gyの傾向が 異なるのは, 空気中では球体の周りのMLCにより照

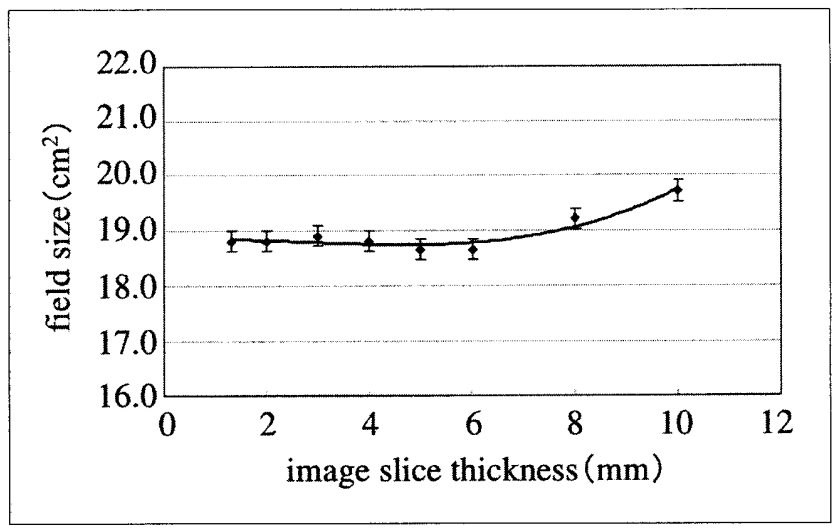

Fig. 5 Change of field sizes when using MLC.

射野面積が変化する部分が空気であるので，空気によ るX線の吸収・散乱が少ないためDMU/Gyの計算結果 にあまり影響を受けないのに対し，水ゲル中では水に よるX線の吸収・散乱の影響を受けるため照射野面積 の変化に上る影響が大きいからであると思われる． MLCの開度の差は, Fig. 7に示すように, 球体ファン トムの端のように形態の変化が大きくなるほど開度の 差が大きくなる。これはスライス厚が薄いほうが MLCのフィッティングが細かく可能であり，形態の 変化に追随できるからである．よって，スライス面内 での急激な形態の変化がある部位では，画像スライス 厚の影響が大きくなるので注意が必要である。

以上の結果より，画像ノイズは，腫瘍位置など照射 範囲が同定できる程度であれば十分に治療計画用の画 像として使用できる。

画像スライス厚に関しては，MLCのサイズ以下で あれば，MLCの開度に変化はなく，照射野面積がほ とんど変化しないので，DMUに影響はない，通常の 外照射では, 呼吸や体動, 位置合わせ時のセットアッ プエラーを考慮し，1 $1 \mathrm{~cm}$ 程度のマージンを取ることが 多く，今回の検討のように $5 \mathrm{~mm}$ 幅のMLCを使用した 装置では，体軸方向の分解能を考慮しても $5 \mathrm{~mm}$ 程度 の画像スライス厚でも問題ないと思われる.

しかし, 強度変調放射線治療 (intensity modulated radiation therapy, IMRT)や定位照射などでは，体軸方向 の分解能を向上させ, 体軸方向座標を正確に求めるた め目的にあった薄い画像スライス厚が必要である.

今回の測定では, 4 検出器のCT装置を使用し, スパ イラルスキャンを行った. 理由は, マルチディテクタ CTでノンスパイラルスキャンを行った場合, 検出器 のエレメント間のセパレータにより, スライス感度分 布 (slice sensitivity profile at Z-axis, SSPz)に窪みを 生じたり，コーンビームの影響を受けるため，4 列お のおのの検出器でSSPzが異なることがある ${ }^{8)}$. 一方ス 


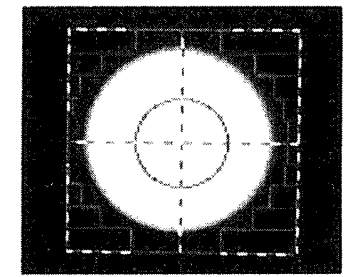

$1.3 \mathrm{~mm}$

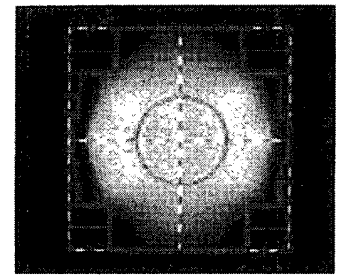

$10 \mathrm{~mm}$

Fig. 6 Position of MLC.

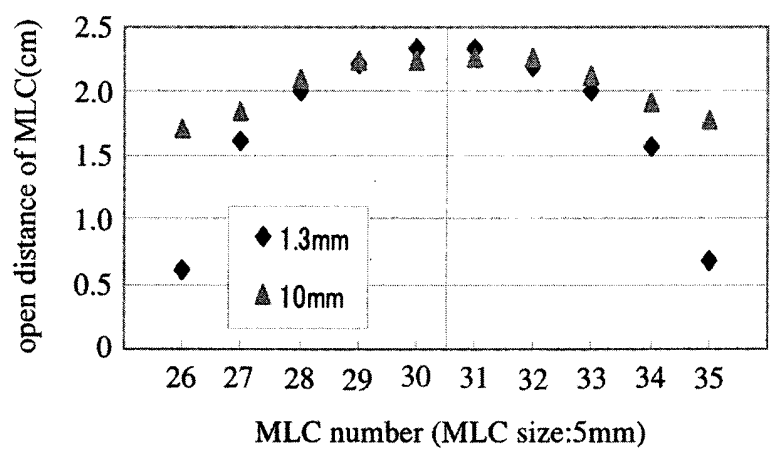

Fig. 7 Open distance of MLC.
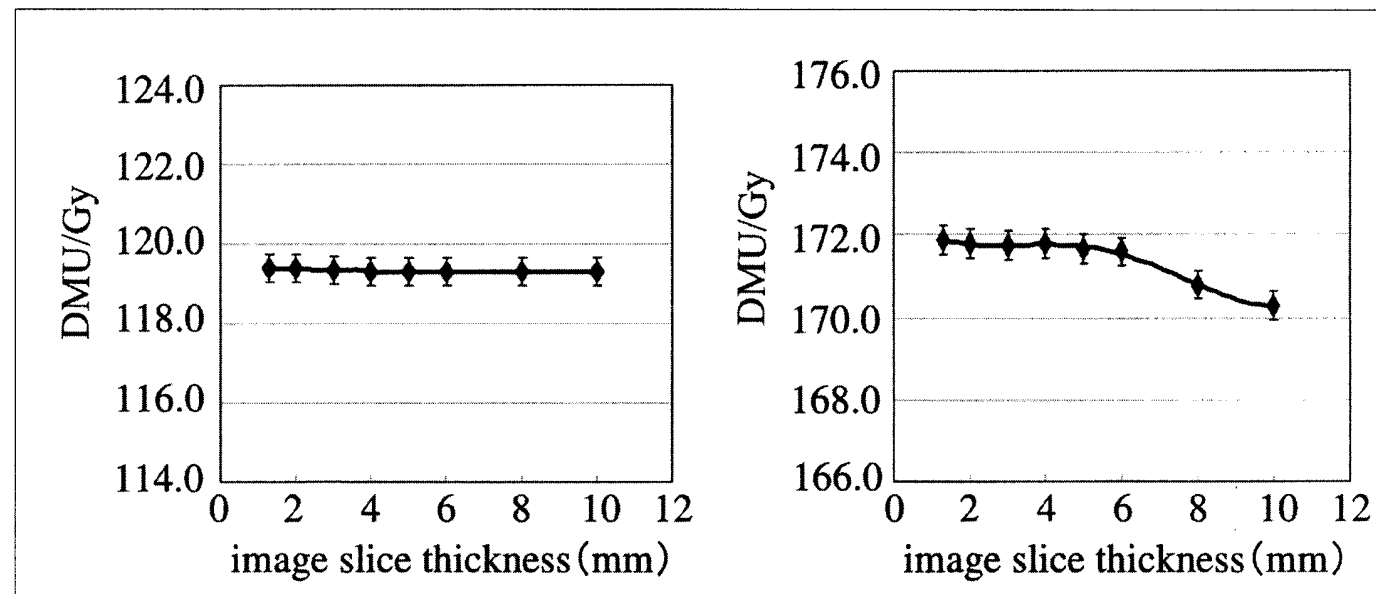

Fig. 8 Change of DMU/Gy at the time of changing image slice thickness, when MLC is used.

(a) In air.

(b) In water.

$a \mid b$

パイラルスキャンでは，スキャンピッチなどのスキャ ン条件によりSSPzが変化するが，Z軸方向のフィルタ リングによって再構成された各画像はほほ同じSSPz となるからである。さらに画像スライス厚に関して は, 微小球体法により確認を行った。臨床での使用に 関しては，各施設のCT装置にて，何らかの方法によ りSSPzの確認は必要であると考える。

\section{4. まとめ}

画像ノイズはDMUには影響しないので, 腫瘍位置
など照射範囲が同定できる程度であれば十分に治療計 画用の画像として使用できる。

画像スライス厚は，MLCサイズ以下であればDMU には影響がなく，また，通常の外照射では，呼吸や体 動，位置合わせ時のセットアップエラーを考慮し， $1 \mathrm{~cm}$ 程度のマージンを取ることが多く，体軸方向の分 解能を考慮しても $5 \mathrm{~mm}$ 程度の画像スライス厚でもよ いと思われる。 


\section{参考文献}

1) 渡辺良晴 : 放射線治療における線量測定デー夕の処理. 日 放技学誌，58(10)，1344-1351，(2002).

2) 金子勝太郎：治療計画一新しい計算アルゴリズムの活用に 向けて一. 日放技学誌, $57(4), 388-392,(2001)$.

3) CT性能評価委員会 : X線コンピュー夕断層撮影装置の性能 評価に関する基準(第二次锥告). 日本医放会誌, 88(8), 758-771, (1982).

4） X線CT装置性能評価検討班：X線CT装置性能評価に関する 基準(案). 日放技学誌，47(1)，56-63，(1991).

5) 木村春樹, 渡辺裕美, 勝田昭一, 他：微小球体を用いた螺
旋状スキャンCTに扔けるスライス感度プロフィール測定の 実際。日放技学誌，53(1)，75，(1997).

6) 勝田昭一, 花井耕造, 国井岳夫, 他：ヘリカルCTにおける スライス感度プロフィールの撮影領域内位置依存性. 日放 技学誌，55(11)，1109-1114，(1999).

7) 原 孝則, 加藤秀記, 青木 力, 他: 不均等型検出器を有 するmulti-slice CTのSSPz と画像ノイズの基礎的検討. 日放 技学誌, 56(12), 1454-1460, (2000).

8) 辻岡勝美：マルチスライスCTの原理. 日放技学誌, 56 (12), 1391-1396, (2000).

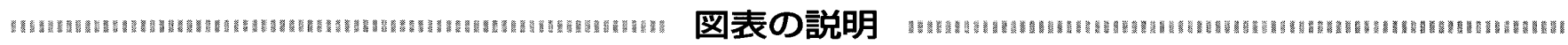

Fig. 1 管電流時間積を変化させた場合の各CT值ファントムにおけるSDの変化

Fig. 2 管電流時間積を変化させた場合の各CT值ファントムにおけるCT值の変化

Fig. 3 管電流時間積を変化させた場合の各CT值ファントムにおけるDMU/Gyの変化

Fig. 4 画像スライス厚を変化させた場合のDMU/Gyの変化

(a) 空気中，(b)水ゲル中

Fig. 5 MLCを使用した時の照射野サイズの変化

Fig. 6 MLCの位置

Fig. 7 各MLCの開度

Fig. 8 MLCを使用した時に画像スライス厚を変化させた場合のDMU/Gyの変化

(a) 空気中, (b) 水ゲル中 